\title{
An Investigation of Teacher Feedback Types and Characteristics in Senior High School Classes
}

\author{
Shiyun $\mathrm{Li}^{1}$ \\ ${ }^{1}$ School of Foreign Languages and Literature, Beijing Normal University, Beijing, China \\ Correspondence: Shiyun Li, School of Foreign Languages and Literature, Beijing Normal University, Beijing, \\ China. E-mail: leeshiyun168@163.com
}

Received: January 8, 2022

Accepted: February 9, 2022

Online Published: February 27, 2022

doi:10.20849/aes.v7i1.1014

URL: https://doi.org/10.20849/aes.v7i1.1014

\begin{abstract}
This paper studies types and characteristics of the teacher classroom feedback through the investigation of 22 classes of 22 senior high school English teachers. Non-participatory observation method was adopted to examine types and characteristics of teacher feedback based on the videos of the 11th National Senior High School English Teaching Demonstration. The purpose of this study is to find out existing problems of teacher feedback so as to improve senior high school English teachers' teaching ability. According to classroom observation and data analysis, the types of the teacher feedback include positive feedback, negative feedback and multiple feedback. The characteristics of the teacher feedback are as follows: among 3 feedback types, positive feedback is the most frequently used one and negative feedback is often used with positive feedback. The existing problems in teachers' feedback are: general feedback including matter-of-fact praise and general praise is often given by teachers; students are often interrupted by teacher feedback; the teacher feedback focuses more on form of student language than on meanings of interaction between teachers and students. In terms of the types, characteristics and problems of teacher feedback, this study gives some suggestions for English teachers in senior high schools to develop their teaching ability of giving feedback.
\end{abstract}

Keywords: teacher feedback, feedback types, feedback characteristics, senior high school English classes

\section{Introduction}

\subsection{Research Background}

With the publication of China's General Senior High School Curriculum Standards for English (2017 edition) (hereinafter called 'CS') launched by The Ministry of Education of the People's Republic of China, the importance of feedback is paid much attention by English teachers. According to the CS, in practical teaching, teachers should deal with the relationship between assessment, teaching and learning, and promote integrated implementation of them. Classroom assessment activities should run through the whole process of teaching for testing teaching objectives. Teachers need to identify problems in student learning and provide timely help and feedback to help students learn more effectively. Teacher feedback is one of most important types of assessment which is emphasized in CS. The vital purpose of senior high school English teaching is to improve Chinese students' English subject core competency which involves developing students' higher-order thinking ability. Teacher feedback is a crucial source for guiding students to reflect on their thoughts and action and is a form of social mediation(Ellis, 2009). It offers teachers an opportunity to examine students' learning condition.

In order to improve senior high school English teachers' feedback quality, this research analyzed 22 teachers' feedback in senior high school teaching cases.

\subsection{Research Questions}

This thesis takes 22 classes of 22 senior high school English teachers as research subjects. Non-participatory observation method was adopted to examine types and characteristics of teacher feedback based on the videos of the 11th National Senior High School English Teaching Demonstration. By analyzing teacher feedback in the demonstration, this research aims to provide some suggestions for teachers to give feedback effectively. According to the objective of this research, the research questions are:

1) What are common types of teacher feedback in senior high school EFL classes? 
2) What are characteristics of English teacher feedback in senior high schools?

3) What are problems of English teacher feedback in senior schools?

\subsection{Research Purpose and Significance}

This thesis makes research about 22 English teachers' feedback in 11th National Senior High School English Teaching Demonstration, aiming to find out the types, characteristics and the existing problems in teachers' feedback, and then put forward some suggestions on the improvement of teacher feedback.

As a useful teaching media, teacher feedback is important to promote students learning ability, which offers chances for students to reflect on their ideas to improve their cognitive development. Appropriate feedback helps students discover and correct mistakes in the learning process as well as achieve psychological satisfaction. Therefore, the research on the feedback of English teachers in class is of great importance.

\section{Literature Review}

\subsection{Definition of Feedback}

Based on Longman Dictionary of Language Teaching and Applied linguistics (2010), feedback refers to "any information that provides information on the result of behaviour". In teaching, feedback refers to comments or other information that learners receive concerning their success on learning tasks or tests, either from the teacher or other people.

\subsection{Types of Feedback}

According to Ellis (2009), there is positive feedback and negative feedback. Positive feedback affirms that a learner response to an activity is correct. It provides affective support to the learner and fosters motivation to continue learning. Negative feedback signals that the learner's utterance lacks veracity or is linguistically deviant.

According to Ellis, Loewen and Erlam (2009), feedback can be implicit and explicit. Metalinguistic explanation and recasts constitute the best exemplars of explicit and implicit corrective feedback which are effective in promoting learning.

According to Lyster and Ranta (1997), there are seven types of feedback: (1) Explicit correction refers to the explicit provision of the correct form; (2) Recasts refer to teacher's reformulation of all or part of a student's utterance; (3) Clarification requests used only after a student error refer to students' problems in comprehensibility or accuracy; (4) Metalinguistic feedback contains comments, information, or questions related to the well-formedness of the student's utterance, without explicitly providing the correct form; (5) Elicitation refers to teachers' utterance used to directly elicit the correct form from the student; (6) Repetition refers to the teacher's repetition, in isolation, of the student's erroneous utterance; (7) Multiple feedback refers to combinations of more than one type of feedback in one teacher turn.

\subsection{Negative Feedback}

Ellis (2009) holds that correcting learners' language is negative feedback. In Ellis' opinion, there are six types of corrective feedback: (1) Recast means the corrector incorporates the content words of the immediately preceding incorrect utterance and changes and corrects the utterance; (2) Repetition means the corrector repeats the learner utterance highlighting the error by means of emphatic stress; (3) Clarification request means the corrector indicates that he/she has not understood what the learner said; (4) Explicit correction means the corrector indicates an error has been committed, identifies the error and provides the correction; (5) Elicitation means the corrector repeats part of the learner utterance but not the erroneous part and uses rising intonation to signal the learner should complete it; (6) Paralinguistic signal means the corrector uses a gesture or facial expression to indicate that the learner has made an error.

Ellis, Loewen and Erlam (2006) define corrective feedback as the inclusion of errors in learners' output to respond to a false statement, usually including: (1) indicating the existence of errors; (2) providing the correct target language form; (3) providing meta-linguistic information indicating the nature of the error, and any combination thereof.

\section{Research Design}

\subsection{Research Objectives}

From the perspective of teachers' feedback, based on the videos of the 11th National Senior High School English Teaching Demonstration, this study aims to draw teachers' attention in feedback, and to offer some suggestions for teachers to give feedback effectively, so as to improve the quality of senior high school English lessons. 


\subsection{Research Subjects}

Twenty-two teaching cases of English teachers of senior high school are regarded as research subjects, who participated in the 11th National Senior High School English Teaching Demonstration. In this study, their videos in the demonstration are collected as the data.

Table 1. Background of the 22 teachers

\begin{tabular}{|c|c|c|c|c|}
\hline $\begin{array}{l}\text { Teacher } \\
\text { Number }\end{array}$ & Province & Grade & Topic & Lesson Type \\
\hline $\mathrm{T} 1$ & Xinjiang & Senior 1 & How Life Began on the Earth & Reading Class \\
\hline $\mathrm{T} 2$ & Jiangxi & Senior 1 & Travel Journal & Reading Class \\
\hline $\mathrm{T} 3$ & Guangdong & Senior 1 & Great Buildings & $\begin{array}{l}\text { Listening and } \\
\text { Speaking Class }\end{array}$ \\
\hline $\mathrm{T} 4$ & Hebei & Senior 1 & The Olympic Games & Reading Class \\
\hline T5 & Fujian & Senior 1 & Friendship & Reading Class \\
\hline T6 & Beijing & Senior 1 & Sea of Green & Reading Class \\
\hline $\mathrm{T} 7$ & Shaanxi & Senior 1 & Wildlife Protection & Reading Class \\
\hline $\mathrm{T} 8$ & Yunnan & Senior 1 & To be a Better Self & $\begin{array}{l}\text { Listening and } \\
\text { Speaking Class }\end{array}$ \\
\hline T9 & Shanghai & Senior 1 & Painter With a Pulse & Reading Class \\
\hline $\mathrm{T} 10$ & Chongqing & Senior 1 & A Trip on "The True North" & Reading Class \\
\hline T11 & Liaoning & Senior 1 & Love You Forever & Reading Class \\
\hline T12 & Guizhou & Senior 1 & The Internet and Telecommunications & Reading Class \\
\hline T13 & Hunan & Senior 1 & Growing Pains & Reading Class \\
\hline T14 & Zhejiang & Senior 1 & & Reading Class \\
\hline T15 & Shanxi & Senior 2 & The Renaissance & Reading Class \\
\hline $\mathrm{T} 16$ & Shandong & Senior 2 & Waiting for Goldie & Reading Class \\
\hline T17 & Hainan & Senior 3 & Breaking Records & Reading Class \\
\hline $\mathrm{T} 18$ & $\begin{array}{l}\text { Inner } \\
\text { Mongolia }\end{array}$ & Senior 2 & Life in The Future & Reading Class \\
\hline T19 & Jilin & Senior 2 & Time to Take E-sports More Seriously & Reading Class \\
\hline $\mathrm{T} 20$ & Tibet & Senior 1 & First Aid for Burns & Reading Class \\
\hline $\mathrm{T} 21$ & Gansu & Senior 2 & Making The News & Writing Class \\
\hline $\mathrm{T} 22$ & Jiangsu & Senior 2 & The Old Man and The Sea & Reading Class \\
\hline
\end{tabular}

\subsection{Research Methodology}

The purpose of this research is to find out the basic types, characteristics and existing problems of teacher feedback in the classes of the twenty-two teachers in the teaching demonstration.

Therefore, this study designs observation sheet of senior high school English teachers' feedback to record the relevant data. After class observation and data collection, Office Excel is used to draw figures and tables to better perform the data analysis.

\subsection{Research Procedure}

This research firstly analyzes literature review on teacher feedback. And then it transcribes teacher feedback in teaching videos and designs observation sheets on the types, characteristics and problems of teacher feedback. After collecting the data, this study will use Office Excel 2010 to analyze the statistics and draw some tables and figures. At last, this research would conclude the types, characteristics and the existing problems in teachers' 
feedback in senior high school and offer some suggestions to improve the quality of teacher feedback.

\section{Data Analysis}

After data collection, this part would analyze the data systematically from the types and characteristics of teacher feedback:

\subsection{Feedback Types of Teacher Feedback}

Teacher's feedback is of great importance in the teaching process, which can be divided into positive feedback and negative feedback. As for positive feedback, teachers usually use general praise, matter-of-fact praise, praise with comments, praise with repetition, and praise with further questioning. The negative feedback teachers used involves explicit correction, elicitation, clarification request and recast.

Table 2 . The percentage of feedback types

\begin{tabular}{|c|c|c|c|}
\hline \multirow{2}{*}{$\begin{array}{l}\text { Items } \\
\text { Teacher } \\
\text { Number }\end{array}$} & \multicolumn{2}{|c|}{ Feedback Types } & \multirow[b]{2}{*}{ Total } \\
\hline & $\begin{array}{l}\text { Positive } \\
\text { Feedback }\end{array}$ & $\begin{array}{l}\text { Negative } \\
\text { Feedback }\end{array}$ & \\
\hline $\mathrm{T} 1$ & 101 & 10 & 111 \\
\hline $\mathrm{T} 2$ & 51 & 4 & 55 \\
\hline T3 & 59 & 11 & 70 \\
\hline $\mathrm{T} 4$ & 88 & 9 & 97 \\
\hline T5 & 60 & 4 & 64 \\
\hline T6 & 71 & 11 & 82 \\
\hline $\mathrm{T} 7$ & 80 & 6 & 86 \\
\hline T8 & 95 & 3 & 98 \\
\hline T9 & 85 & 18 & 103 \\
\hline T10 & 62 & 3 & 65 \\
\hline T11 & 41 & 12 & 53 \\
\hline T12 & 68 & 8 & 76 \\
\hline T13 & 114 & 13 & 127 \\
\hline T14 & 101 & 4 & 105 \\
\hline T15 & 85 & 10 & 95 \\
\hline T16 & 78 & 9 & 87 \\
\hline T17 & 52 & 4 & 56 \\
\hline T18 & 110 & 9 & 119 \\
\hline T19 & 76 & 9 & 85 \\
\hline $\mathrm{T} 20$ & 89 & 8 & 97 \\
\hline $\mathrm{T} 21$ & 61 & 2 & 63 \\
\hline $\mathrm{T} 22$ & 61 & 14 & 75 \\
\hline Total & 1688 & 181 & 1869 \\
\hline Percentage & $90.3 \%$ & $9.7 \%$ & $100 \%$ \\
\hline
\end{tabular}

From the Table 2, it is clear that positive feedback $(90.3 \%)$ is the most common in the class. Positive feedback can strengthen students' self-confidence and motivation in English learning and promote the teaching process. The proportion of negative feedback accounts for $9.7 \%$. Teachers have responsibilities to point out mistakes 
directly or indirectly to students and appropriate negative feedback can let students discover their mistakes and correct them in time. However, teachers are less likely to use it which may not improve students' cognitive development.

Table 3. The percentage of multiple feedback

\begin{tabular}{|c|c|c|c|}
\hline Items & & k Types & \\
\hline$r$ & $\begin{array}{l}\text { Multiple } \\
\text { Feedback }\end{array}$ & $\begin{array}{l}\text { Negative } \\
\text { Feedback }\end{array}$ & Rate \\
\hline T1 & 6 & 10 & $60.0 \%$ \\
\hline $\mathrm{T} 2$ & 3 & 4 & $75.0 \%$ \\
\hline $\mathrm{T} 3$ & 4 & 11 & $36.4 \%$ \\
\hline T4 & 3 & 9 & $33.3 \%$ \\
\hline T5 & 1 & 4 & $25.0 \%$ \\
\hline T6 & 4 & 11 & $36.4 \%$ \\
\hline T7 & 2 & 6 & $33.3 \%$ \\
\hline T8 & 1 & 3 & $33.3 \%$ \\
\hline T9 & 6 & 18 & $33.3 \%$ \\
\hline T10 & 2 & 3 & $66.7 \%$ \\
\hline T11 & 6 & 12 & $50.0 \%$ \\
\hline T12 & 6 & 8 & $75.0 \%$ \\
\hline T13 & 10 & 13 & $76.9 \%$ \\
\hline T14 & 2 & 4 & $50.0 \%$ \\
\hline T15 & 5 & 10 & $50.0 \%$ \\
\hline T16 & 6 & 9 & $66.7 \%$ \\
\hline T17 & 3 & 4 & $75.0 \%$ \\
\hline T18 & 5 & 9 & $55.6 \%$ \\
\hline T19 & 2 & 9 & $22.2 \%$ \\
\hline T20 & 2 & 8 & $25.0 \%$ \\
\hline $\mathrm{T} 21$ & 1 & 2 & $50.0 \%$ \\
\hline $\mathrm{T} 22$ & 2 & 14 & $14.3 \%$ \\
\hline Average & 82 & 181 & $45.3 \%$ \\
\hline
\end{tabular}

In this article, multiple feedback refers to the combination of positive feedback and negative feedback which means teachers often give negative feedback after giving positive feedback. It is sometimes used by teachers to avoid hurting students' self-esteem caused by single negative feedback. The proportion of multiple feedback accounts for $45.3 \%$ when teachers give negative feedback, which means teachers often give negative feedback after giving positive feedback first. Sometimes, multiple feedback can not only protect students' psychological needs, but also give students more impressive feedback. So when correcting mistakes, teachers can try to use more multiple feedback in class. 


\subsection{Characteristics of Teacher Feedback}

Table 4 . The percentage of positive feedback

\begin{tabular}{|c|c|c|c|c|c|c|}
\hline \multirow{4}{*}{$\begin{array}{l}\text { Items } \\
\text { Teacher } \\
\text { Number }\end{array}$} & \multicolumn{5}{|c|}{ Positive Feedback } & \multirow{4}{*}{ Total } \\
\hline & General & Matter-of-fact & Praise With & Praise With & Praise With & \\
\hline & Praise & Praise & Comments & Repetition & Further & \\
\hline & & & & & Questioning & \\
\hline $\mathrm{T} 1$ & 35 & 44 & 2 & 13 & 7 & 101 \\
\hline $\mathrm{T} 2$ & 14 & 18 & 1 & 15 & 3 & 51 \\
\hline $\mathrm{T} 3$ & 29 & 9 & 4 & 13 & 4 & 59 \\
\hline $\mathrm{T} 4$ & 18 & 50 & 2 & 13 & 5 & 88 \\
\hline $\mathrm{T} 5$ & 19 & 10 & 6 & 16 & 9 & 60 \\
\hline T6 & 31 & 20 & 3 & 12 & 5 & 71 \\
\hline $\mathrm{T} 7$ & 25 & 26 & 2 & 21 & 6 & 80 \\
\hline $\mathrm{T} 8$ & 20 & 28 & 11 & 18 & 18 & 95 \\
\hline T9 & 22 & 30 & 1 & 16 & 16 & 85 \\
\hline $\mathrm{T} 10$ & 20 & 22 & 3 & 14 & 3 & 62 \\
\hline $\mathrm{T} 11$ & 7 & 24 & 4 & 2 & 4 & 41 \\
\hline $\mathrm{T} 12$ & 14 & 20 & 3 & 13 & 18 & 68 \\
\hline $\mathrm{T} 13$ & 36 & 38 & 0 & 28 & 12 & 114 \\
\hline $\mathrm{T} 14$ & 26 & 34 & 4 & 26 & 11 & 101 \\
\hline $\mathrm{T} 15$ & 27 & 28 & 3 & 21 & 6 & 85 \\
\hline $\mathrm{T} 16$ & 9 & 27 & 6 & 22 & 14 & 78 \\
\hline $\mathrm{T} 17$ & 20 & 15 & 2 & 12 & 3 & 52 \\
\hline $\mathrm{T} 18$ & 28 & 41 & 1 & 28 & 12 & 110 \\
\hline $\mathrm{T} 19$ & 14 & 38 & 1 & 20 & 3 & 76 \\
\hline $\mathrm{T} 20$ & 26 & 28 & 1 & 28 & 6 & 89 \\
\hline $\mathrm{T} 21$ & 25 & 13 & 0 & 22 & 1 & 61 \\
\hline $\mathrm{T} 22$ & 11 & 20 & 1 & 19 & 10 & 61 \\
\hline Total & 476 & 583 & 61 & 392 & 176 & 1688 \\
\hline Percentage & $28.3 \%$ & $34.5 \%$ & $3.6 \%$ & $23.2 \%$ & $10.4 \%$ & $100 \%$ \\
\hline
\end{tabular}

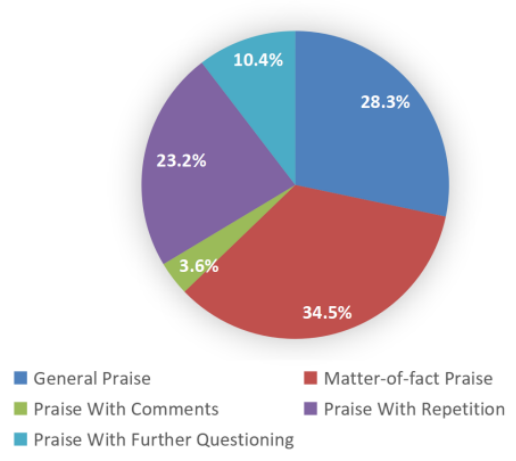

Figure 1. The percentage of positive feedback 
According to the transcripts of the videos, five types of positive feedback are found. In this article, general praise refers specifically to teacher utterances that only contain positive terms like thanks, good, very good, excellent, well done, and the like. Matter-of-fact praise refers to teacher utterances including yes, right, okay, correct and the like. Praise with comments refers to teacher utterances involving comment on the content of students' answers such as good sentence, good phrases, and the like. Praise with repetition refers to teachers' repetition or synthesizing of students' correct answers. Praise with further questioning refers to teachers' further questioning based on students' previous answers.

From the Table 4 and Figure 1, we can see the proportion of matter-of-fact praise accounts for 34.5\%, which is the highest among the five groups. So the teachers usually give students feedback by using "yes/right/ok". This kind of feedback can give students' confidence by confirming the utterance of students. The proportion of general praise accounts for $28.3 \%$. This kind of positive feedback often refers to mechanically-used praise words, which will not have a significant positive influence on students. Therefore, sometimes the teachers will also repeat $(28.1 \%)$ or further question $(17.4 \%)$ or even comment $(11 \%)$ on what students had said, which is more concrete than general praise and students will be more willing to answer questions and be more confident.

Table 5. The percentage of negative feedback

\begin{tabular}{|c|c|c|c|c|c|}
\hline \multirow{3}{*}{$\begin{array}{l}\text { Items } \\
\text { Teacher } \\
\text { Number }\end{array}$} & \multicolumn{4}{|c|}{ Negative Feedback } & \multirow{3}{*}{ Total } \\
\hline & $\begin{array}{l}\text { Explicit } \\
\text { correction }\end{array}$ & Elicitation & $\begin{array}{l}\text { Clarification } \\
\text { Request }\end{array}$ & Recast & \\
\hline & & & & & \\
\hline $\mathrm{T} 1$ & 1 & 1 & 0 & 8 & 10 \\
\hline $\mathrm{T} 2$ & 0 & 2 & 0 & 2 & 4 \\
\hline T3 & 0 & 5 & 2 & 4 & 11 \\
\hline $\mathrm{T} 4$ & 1 & 7 & 0 & 1 & 9 \\
\hline $\mathrm{T} 5$ & 0 & 3 & 0 & 1 & 4 \\
\hline T6 & 1 & 6 & 0 & 4 & 11 \\
\hline $\mathrm{T} 7$ & 1 & 4 & 0 & 1 & 6 \\
\hline T8 & 0 & 1 & 0 & 2 & 3 \\
\hline T9 & 4 & 3 & 1 & 10 & 18 \\
\hline $\mathrm{T} 10$ & 1 & 0 & 1 & 1 & 3 \\
\hline $\mathrm{T} 11$ & 6 & 2 & 2 & 2 & 12 \\
\hline $\mathrm{T} 12$ & 2 & 5 & 0 & 1 & 8 \\
\hline $\mathrm{T} 13$ & 3 & 6 & 2 & 2 & 13 \\
\hline $\mathrm{T} 14$ & 0 & 1 & 1 & 2 & 4 \\
\hline $\mathrm{T} 15$ & 3 & 2 & 3 & 2 & 10 \\
\hline T16 & 6 & 1 & 0 & 2 & 9 \\
\hline T17 & 2 & 0 & 0 & 2 & 4 \\
\hline T18 & 2 & 4 & 0 & 3 & 9 \\
\hline T19 & 1 & 6 & 2 & 0 & 9 \\
\hline $\mathrm{T} 20$ & 4 & 2 & 1 & 1 & 8 \\
\hline $\mathrm{T} 21$ & 0 & 1 & 1 & 0 & 2 \\
\hline $\mathrm{T} 22$ & 0 & 8 & 2 & 4 & 14 \\
\hline Total & 38 & 70 & 18 & 55 & 181 \\
\hline Percentage & $21.0 \%$ & $38.7 \%$ & $9.9 \%$ & $30.4 \%$ & $100 \%$ \\
\hline
\end{tabular}




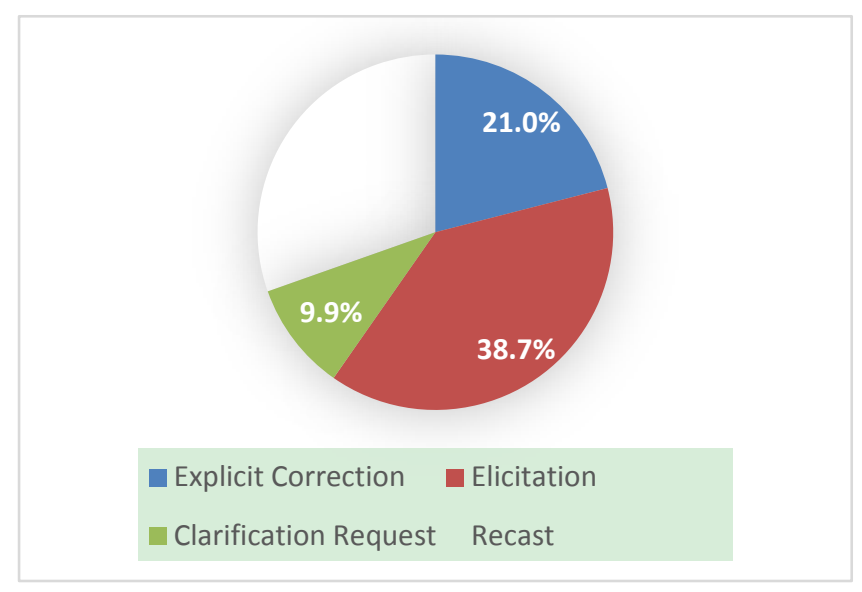

Figure 2. The percentage of negative feedback

From the Table 5 and Figure 2, we can see that the percentage of elicitation accounts for $38.7 \%$ which is the highest among the four types of negative feedback. Elicitation means that the teacher repeats part of the learner utterance but not the erroneous part so it is usually used to guide students to think more as well as maintain students' face.

Recast (30.4\%) is also used frequently by the teachers, which means that the teacher repeats the students' answers to some extent, but skillfully corrects the small mistakes in the students' answers in the meantime.

Here is an example from Teacher 1 who uses elicitation and recast:

Teacher: How about para D?

Student 1: D (pause).

Teacher: The first sentence. (Elicitation, using rising intonation)

Student 1: Many middle of the years later of universe. (wrong words)

Teacher: Yes. Many millions of years later and how about the last one

of universe? (Recast)

Student 1: Last one is about the finally.

Teacher: Yes. Finally. Very good. Thank you. Sit down please.

The next negative feedback is explicit correction $(21.0 \%)$, which means that the teacher directly points out the students' mistakes. The teachers would tell the students by saying: "That's wrong. We should say...in English". Explicit correction can save some time, but it may lower students' confidence and their interest in engaging in classroom learning and interaction.

The last one is clarification request (9.9\%), which refers to that when the students are making some mistakes, such as pronunciation or grammar, the teachers will repeat students' wrong utterance and sometimes give them right answers together to request them to choose or clarify their answers again. This feedback can provide students an opportunity to rethink and reflect on their original answers.

Here is an example from Teacher 18 who uses clarification request and recast:

Student 1: Nervous and uncertain. (wrong pronunciation)

Teacher: Nervous and? (Clarification request)

Student 1: Uncertain (wrong pronunciation).

Teacher: Uncertain. (Recast)

Student 1: Uncertain.

Teacher: Yes. So we can use one word. That is uncertain (speak slowly). Very good

To sum up, teacher feedback including positive feedback or negative feedback or multiple feedback can facilitate learners' learning to some extent. Therefore, teachers should use positive and negative feedback flexibly to encourage students and facilitate their language learning. The main problems of teacher's classroom feedback: 
students' utterance is often interrupted by teachers; the feedback is not specific; matter-of-fact and simple praise appear too many times; the positive feedback is short of praise focused on the meaning of students' language like praise with comment.

\section{Conclusion}

\subsection{Research Findings}

This research investigated 22 teachers' feedback in senior high school based on national high-quality senior high English classroom teaching cases. On the basis of classroom observation and data analysis, this study examined types and characteristics of teacher feedback, intending to find out the existing problems of feedback in senior high school English teachers. The existing problems in teachers' feedback are: general feedback including matter-of-fact praise and general praise is often given by teachers; students are often interrupted by teacher feedback; the teacher feedback focuses more on forms of student language than on meanings of interaction between teachers and students. The research results show that teachers prefer to use matter-of-fact praise in positive feedback and elicitation in negative feedback. So it is suggested to give students enough time to think and organize the answers after posing a question, offer them more concrete feedback and try to use more logical question chains to inspire students to think more. Sometimes teachers need to be more patient and decide whether to interrupt them or not based on the teaching objectives. For example, if the class focuses on speaking fluency, teachers may better give feedback after students' utterance. The class should be student-centered so teachers should pay more attention to the students' learning should let students think about and discuss those questions. Besides, teachers need to correct students more effectively. If students' answers are wrong, teachers should use some negative feedback like explicit correction, elicitation and recast rather than neglecting them all the time just to maintain students' confidence.

\subsection{Limitations and Recommendations}

This research only selects twenty-two senior high teachers' teaching cases as subjects and only types and characteristics of teacher feedback are studied, which is not so comprehensive. There are also some other perspectives about teacher feedback can be further analyzed, such as the time between student utterance and teacher feedback and the variety of the content of teacher feedback and interview some students' thoughts about their ideal feedback. In addition, whether corrective feedback is effective needs to solve these questions: (1) What kind of mistakes to correct; (2) who will correct it; (3) What kind of corrective feedback is most effective; (4) What is the best time to correct feedback? Immediate or delayed correction? However, there is no unified solution to these problems. Ellis (2009) suggested that teachers should base themselves on the classroom and seek for methods suitable for their students through empirical research data. Nunan (1991) said that much of the feedback provided by teachers often seems to be rather automatic so its ultimate effect on the learners is doubtful. So teachers need to become a researcher as well so as to use feedback more effectively to promote learners' learning.

\section{References}

Ellis, R. (2009). Corrective Feedback and Teacher Development. L2 Journal, 1, 3-18

Ellis, R., Loewen, S., \& Erlam, R. (2006). Implicit and Explicit Corrective Feedback And The Acquisition Of L2 Grammar. Studies in Second Language Acquisition, 28, 339-368

Lyster, R., \& Ranta, L. (1997). Corrective Feedback and Learner Uptake. Studies in Second Language Acquisition, 20, 37-66.

Nunan, D. (1991). Language Teaching Methodology: A Textbook for Teachers. New York: Prentice Hall.

Richards, J., \& Schmidt, R. (2010). Longman Dictionary of Language Teaching and Applied Linguistics (4th ed.). Pearson.

The Ministry of Education of the People's Republic of China. (2017). General Senior High School Curriculum Standards for English (2017 edition). Beijing: People's Education Press. (In Chinese)

\section{Copyrights}

Copyright for this article is retained by the author(s), with first publication rights granted to the journal.

This is an open-access article distributed under the terms and conditions of the Creative Commons Attribution license (http://creativecommons.org/licenses/by/4.0/). 